\title{
Impact of convection over the equatorial trough on the summer monsoon activity over India
}

M. R. Ramesh Kumar ${ }^{1}$ and S.S.C. Shenoi

Physical Oceanography Division

National Institute of Oceanography

Jörg Schulz ${ }^{2}$

Deutscher Wetterdienst, Satellite Application Facility on Climate Monitoring, Dept. Climate and Environment, P.O. Box 1004 65, 63004 Offenbach, Germany

\begin{abstract}
The cause for the disruption of rainfall (break in monsoon conditions) over the Indian subcontinent during the monsoon months, for the period, $1979-1998$, are investigated using the pentad rainfall data from the Global Precipitation Climatology Project (GPCP). Most (about $73 \%$ ) of the break in monsoon (BM) events were associated with the convective activity (rainfall more than $30 \mathrm{~mm} /$ pentad) over the equatorial trough (ET) region. The association between these events and the convective activity over the western (WET) and eastern equatorial trough (EET) regions of the tropical Indian Ocean were further explored. These relationships were tested for different (deficit, normal and excess) monsoon conditions over the Indian subcontinent and the El Nino conditions in the Pacific Ocean.

There appears to be a negative and significant correlation between the Central Indian Region (CIR) rainfall and EET during deficit and non El Nino years. During deficit and El Nino years, the CIR rainfall exhibited a negative correlation with WET. In the case of years with no breaks, the EET was negatively (positively) correlated during the years 1982 \& 1992 (1994 \& 1997) with the all India rainfall (AIR). The convective activity was more intense over the EET than WET during prolonged BM and also in a deficit and non El Nino year (1979). The probabilities of occurrence of no BM conditions are more in the El Nino years. The number of lows and depressions, in general, were also more in the years when there were no BM events.
\end{abstract}

Key Words: Convection, Precipitation, Monsoon, Equatorial Trough, Break

Regional Index Terms: Indian Ocean, Equatorial, Indian subcontinent.

\footnotetext{
${ }^{1}$ Corresponding author address: Dr. M. R. Ramesh Kumar, Physical Oceanography Division, National Institute of Oceanography, Dona Paula, Goa - 403004, India; E-mail: kramesh@nio.org

${ }^{2}$ Deutscher Wetterdienst, Satellite Application Facility on Climate Monitoring, Dept. Climate and Environment, P.O. Box 1004 65, 63004 Offenbach, Germany
} 


\section{Introduction}

The southwest monsoon, which gives about $60-80 \%$, of the mean annual rainfall of the various meteorological sub-divisions of India is the most outstanding feature of the Indian meteorology (Ananthakrishnan et al., 1983). Hence it is quite important to understand its intra-seasonal and inter-annual variability. There are several factors, which affect the inter-annual variability in the monsoon. One among them is the disruption of monsoon activity within the life cycle - the break in monsoon conditions. Earlier studies (Ramamurty, 1969; Murakami and Frydrich, 1974; Murakami, 1976; Krishnamurti and Bhalme, 1976) have related the break in monsoon (BM) conditions with various synoptic situations.

Ramamurty (1969) suggested different synoptic situations associated with BM, such as, the migration of monsoon trough to the foot hills of Himalayas, the absence of low level easterly winds over the northern India and increased rainfall activity in the foot hills of Himalayas and decrease of rainfall over the rest of the country. His analysis, further showed that, breaks in general, persists usually for 3 to 4 days and very rarely they last for longer period of 17 to 20 days. Murakami and Frydrich (1974) and Murakami (1976) have also looked into the fluctuations between active and break in BM on a quasi-biweekly time scale. Krishnamurti and Bhalme (1976) suggested that the alternations between active and break spells could result from large-scale cloud feed back and large-scale radiative effects. Swapna and Ramesh Kumar (2002) showed that the BM were associated with the transport of moisture into the equatorial Indian Ocean, while looking at the monsoon activity of two contrasting monsoon years (1987 and 1988). In a recent study, Ramesh Kumar and Uma Prabhu Dessai (2004) have defined new criteria for the break in monsoon conditions over the Indian subcontinent based purely on the all India monsoon rainfall, which they feel that is truly representative of the monsoon conditions over the Indian subcontinent. According to their criterion, they classified a break as one when the daily all India rainfall in the months of July and August is less than $9 \mathrm{~mm}$ for three consecutive years, similarly they classified the active conditions as days when the all India daily rainfall is more than $15 \mathrm{~mm}$ and persists for three days.

There have been studies (Cadet and Olory Togbe, 1981; Sadhuram and Sastry, 1987) on the role of Equatorial Trough (ET) as well as Southern Hemispheric Equatorial Trough (SHET) on the rainfall over central India. Most of these studies are related to the analysis of satellite-derived cloudiness over the equator and monsoon activity over India (Prasad et al., 1983; Prasad et al., 1988; Johri and Prasad, 1990). Cadet and Olory Togbe (1981) included, the pressure and wind field, in addition, to the cloudiness and concluded that the SHET is well marked during break in monsoon conditions. They also observed that during active monsoon conditions, the SHET 
though present was less marked. Prasad et al., (1983) have shown that there exists an inverse relationship between the cloudiness in the SHET (equator to $10^{\circ} \mathrm{S}$, over the Indian Ocean) and the rainfall activity over central India. Sadhuram and Sastry (1987), also found, an inverse relationship between Gan island $\left(0^{\circ} 42^{\prime}, 7^{\circ} 10^{\prime}\right)$ rainfall (which they have taken as a representative for the SHET region), with the rainfall over central India (average of 20 rainfall stations in the state of Madhya Pradesh). Prasad et al., (1988) further found that the sudden increase in cloudiness is confined to the east of $70^{\circ} \mathrm{E}$ or $75^{\circ} \mathrm{E}$. Johri and Prasad (1990) using satellite cloudiness data showed that the development of different phases of the monsoon depends on the intensity of SHET. Thus most of these studies have shown that the SHET serves to regulate the airflow from the southern hemisphere and thereby leads to the development of different phases of southwest monsoon.

Most of the earlier estimates of precipitation over the Oceans [Baumgartner and Reichel (1975)] were derived by direct interpolation of measurements from gauges at coastal and island stations. But the fact remains that most parts of the Oceans are far away from land based stations; and also there are significant differences between the precipitation processes over the land and seas.

One of the major drawbacks of the study of precipitation, is that very little is known about its spatial and temporal distribution. This is all the more because of the limited distribution of the conventional recording instrument such as a rain gauge and radar are in adequate to describe it suitably. The problem is further complicated, when one thinks of oceanic rainfall, where conventional recording instruments such as rain gauges are non-existent. The satellite sensors seem to be the only source for providing continuous data over the oceans in both space and time. Barrett and Beaumont (1994), in a recent overview have shown the potential for improving the precipitation estimates using satellite data. One of the major needs envisaged by them was the need for calibration and validation of satellite algorithms intended for full operational use especially over the Oceans where in situ data are particularly sparse such as the Indian Ocean.

Several authors have used different parameters as a proxy for the convective activity over the Ocean such as Sea Surface Temperature (SST), Cloudiness, Highly Reflective Cloudiness (HRC), Outgoing Longwave Radiation (OLR) and satellite estimates of Rainfall. In fact, most the above-mentioned parameters are now routinely obtained from remotely sensed data from satellites, which are important for looking at the data sparse regions such as the Indian Ocean.

Space based measurement and monitoring of cloudiness and rainfall has improved dramatically over the past three decades. In early years, the visible and infrared data from the polar and geo 
stationary satellites were used for the rainfall estimates as they were continuously available for large areas and better temporal resolutions. In general, they were based on an empirical relationship between cloud top temperature and rainfall measured at the ground or at sea. Since these techniques were an indirect method of measuring the rainfall and empirical in nature, the relationship varied with season and region.

The microwave measurement of rainfall estimates from satellites have been recognized as far better than the visible and infrared methods because they could provide the direct estimates of rainfall over both land and ocean. Most of the microwave estimates of rainfall have come from passive microwave measurements. With advent of the recent space borne Precipitation Radar (PR) onboard the Tropical Rainfall Measuring Mission (TRMM) and multi frequency passive microwave radiometer on (TRMM Microwave Imager, TMI) have provided better estimates of precipitation.

In the present study, we examine, the relationship between the break in monsoon period and the convective activity over ET. The objectives of the study are to look into the following aspects a) Is there any relationship between convective activity over the ET, Western Equatorial Trough (WET) and Eastern Equatorial Trough (EET) and the monsoon activity over the Central India Region (CIR) and All India Rainfall (AIR)? b) Does the convection over the ET, WET and EET behave in a similar fashion during different monsoon and El Nino conditions ? c) What role do the synoptic systems play during the BM over the Indian subcontinent?

\section{Data and Methodology}

The pentad precipitation data used in the present study is obtained from the Global Precipitation Climatology Project (GPCP). The GPCP was established by the World Climate Research Program in 1986 to address the problem of quantifying the distribution of precipitation over the whole globe. The general approach of the project is to combine the precipitation information available from each source into a final merged product, taking advantage of the strengths of each type of data. The microwave estimates are based on the Special Sensor Microwave/Imager (SSM/I) data from the Defense Meteorological Satellite Program (DMSP, U.S) and the infrared estimates are primarily obtained from geo-stationary satellites operated by U.S, Europe and Japan and secondarily from polar orbiting satellites. More details of the GPCP can be had from Huffman et al., (1997). No data from the Indian National Satellite (INSAT) or rain gauge data from the Indian subcontinent or islands in the Arabian Sea and Bay of Bengal were included in the GPCP data set. 
In order, to gain confidence in these datasets, we have validated satellite derived estimates of Tropical Rainfall Monitoring Mission (TRMM) Microwave Imager (TMI) data, GPCP data and National Centre Environmental Prediction (NCEP/NCAR) Reanalysis data (Kalnay et al., 1996) with four island stations two in the Arabian Sea $\left[\right.$ Amini $\left(11^{\circ} \mathrm{N} ; 72^{\circ} \mathrm{E}\right)$ and Minicoy $\left(8.5^{\circ} \mathrm{N}\right.$; $\left.73^{\circ} \mathrm{E}\right)$ ] and two in the Bay of Bengal [ Port Blair $\left(11.5^{\circ} \mathrm{N} ; 93^{\circ} \mathrm{E}\right)$ and Car Nicobar $\left.\left(9^{\circ} \mathrm{N} ; 93^{\circ} \mathrm{E}\right)\right]$.

The spatial and temporal correlation between the rainfall over the four island stations and the rainfall estimates from GPCP, TMI and NCEP/NCAR Reanalysis are given in table 1. From the table it can be seen that the correlation coefficients are much better in the case of GPCP $(\mathrm{r}=0.29)$ than the TMI $(\mathrm{r}=0.14)$ and NCEP $(0.21)$ for one-day period. When we tried for correlating for the pentad ( 5 day) period the correlation coefficient increased dramatically in the case of the GPCP $(r=0.62)$ as compared to the TMI $(r=0.37)$ and NCEP $(0.44)$, showing that the GPCP is able to pick up the rainfall variability of theses stations quite well. The correlations increased only slightly in the case of 10 days and for all the three estimates. In the case of 30day periods, the correlations were high for all the three estimates, with the GPCP having the maximum correlation.

In a recent study, Yin et al., (2004) have shown that the GPCP data is better suited for looking at the oceanic precipitation than the CMAP merged Gauge -satellite monthly precipitation estimates. They found that the CMAP precipitation was showing a decreasing trend in oceanic precipitation, which could be due to an artifact of the input data change and atoll sampling error.

The data pertaining to the all India monsoon rainfall is taken from Parthasarathy et al., (1994) and further updated up-to 1998 using the rainfall data set from the Indian Institute of Tropical Meteorology, Pune, India. The mean rainfall for the study period is $832.1 \mathrm{~mm}$ and the standard deviation is $79.4 \mathrm{~mm}$. A year is considered deficit (excess) monsoon year, if the seasonal rainfall from the mean for the study period is less (more) than one standard deviation, otherwise it is considered as normal monsoon year. There were 11 (55\% of the study years, see Table 2) normal monsoon years, which were also non El Nino years. Further, we had two (one) excess monsoon years without El Nino (with El Nino). There were four deficit monsoon years, among them two were El Nino years (1982 and 1987) and two were non El Nino years (1979 and 1986).

We define the equatorial trough (ET) region as the area bounded between the equator and $10^{\circ} \mathrm{S}$ and between the longitudes $60^{\circ} \mathrm{E}-100^{\circ} \mathrm{E}$. In order to look into the variability of convection over the ET, we consider a threshold limit of $30 \mathrm{~mm} /$ pentad. We assume, the ET as convectively active if the rainfall over ET is more than $30 \mathrm{~mm} /$ pentad (i.e approximately $6 \mathrm{~mm} /$ day). We 
have further divided the ET into two equal halves, the western part $\left(60^{\circ} \mathrm{E}-80^{\circ} \mathrm{E}\right)$, which we will call as western equatorial trough (WET) and the eastern part $\left(80^{\circ} \mathrm{E}-100^{\circ} \mathrm{E}\right)$, which we will refer to as eastern equatorial trough (EET). We have used the daily all India rainfall (AIR) data obtained from IITM, Pune, India, to monitor the monsoon activity over the Indian subcontinent, and also the rainfall data of the central Indian region $\left(20^{\circ} \mathrm{N}-24^{\circ} \mathrm{N} ; 74^{\circ} \mathrm{E}-88^{\circ} \mathrm{E}\right)$, to monitor the above relationships. Figure 1 depicts the various areas used in the present study. The BM data is taken from De et al., (1998) who classified the BM days following the criteria of Ramamurty (1969).

\section{Results and discussion}

\subsection{Break in monsoon conditions}

Table 2 gives the details of the various break periods during the study as well as the BM days. We have looked into the BM conditions for the months of July and August, only, for the reason that a delayed onset or early withdrawal can create artificial breaks during June or September, further these are the months which contribute about $62 \%$ of the mean monsoon rainfall (Ramesh Kumar and Uma Prabhu Dessai, 2004). For the present study, most of the years had one or two monsoon breaks, with the exception of the years, 1982, 1992, 1994 and 1997, which had no breaks (table 2) at all. The years 1979 and 1998 on the other hand had maximum BM days of 27 and 21 respectively and also three prolonged break periods, one from $15^{\text {th }}$ August to $3^{\text {rd }}$ September in 1979 and two were in 1998 ( $16^{\text {th }}$ to $25^{\text {th }}$ July $; 21^{\text {st }}$ to $31^{\text {st }}$ August, 1998). Majority of the years had only one break ( 8 years), while there were two breaks ( 7 years) and four years had no breaks at all. Further, the month of July (August) had 12 (8) breaks during the present study.

\subsection{Equatorial trough and monsoon rainfall}

The Indian summer monsoon has vigorous intra-seasonal oscillations in the form of active and weak (or break) spells of monsoon rainfall within the monsoon season (Ramamurty, 1969). These active and weak (break) monsoon conditions are associated with fluctuations of tropical convergence zones. Figure 2 gives the seasonal mean precipitation for the tropical Indian Ocean derived from the GPCP climatological pentad data. It has two major zones of precipitation, one extending from monsoon trough to the head Bay of Bengal and a secondary zone of precipitation lies south of the equator (between $0^{\circ}-10^{\circ} \mathrm{S}$ ). These two maxima in seasonal precipitation are the preferred locations for the convergence zones, namely the monsoon trough 
or the continental tropical convergence zone and the oceanic convergence zone (Sikka and Gadgil, 1980; Goswami, 1994) over the ET. The intra-seasonal oscillations are the fluctuations of the convergence zones within the above two favored locations. In the intra seasonal time scale, the tropical convergence zones form repeatedly over the oceans and progress northwards to the continental convergence zone or the monsoon trough, where it persists for some time and then decays and again regenerates over the Ocean.

Recent study of Gadgil et al (2003) has shown that equatorial Indian Ocean plays equally important role as that of the El Nino Southern Oscillation (ENSO) in the Pacific Ocean on the Indian summer monsoon. They found that the enhancement of deep convection in the atmosphere over the western part is generally associated with the suppression over the eastern part and vice versa. Their study further could explain all the excess/deficit monsoon seasons in terms of favourable Equatorial Indian Ocean Oscillation (EQUNIOO) or ENSO or both.

In another study, Gadgil and Joseph (2003) have shown that the rainbreaks (active spells) over the Indian subcontinent are associated with negative (positive) anomalies over a part of the east Pacific suggesting that the convection over the Indian region is linked to that of east Pacific region at intra seasonal scale also.

In order, to look into the role of the convective activity over the ET during different years and monsoon conditions, we have plotted the rainfall over the ET (figure 3). From figure 3, it is obvious that, ET was quite active (rainfall more than $30 \mathrm{~mm} /$ pentad) during most of season in 1979; it had two prolonged BM's. This compares well with all India daily rainfall values for the months of July and August, which were low, indicating the weak monsoon conditions prevailing during these days. Further this year had maximum number of BM days (27 days) in the months of July and August. Another interesting aspect of this year is that the monsoon never recovered from this prolonged break spell as can be seen from the active conditions of the ET region during the month of September. When there were no breaks (1982, 1992, 1994, 1997), the convective activity over ET was below the threshold value of $30 \mathrm{~mm} /$ pentad during most of the monsoon period. Further, in several years (more than 10 years) the ET was active one or two pentads (10 days) prior to BM, indicating the possibility of the convective activity over ET foreshadowing the BM conditions over the Indian subcontinent, which agrees well with the recent study of Wang et al (2005) who suggested that the active/break in monsoon conditions can be predicted about 4 weeks in advance. 


\subsection{Convective activity over the WET and EET during different BM and El Nino conditions}

Wang et al (2005) have shown that western equatorial Indian Ocean (WEIO) plays a critical role in predicting the antecedents of the active/break monsoon conditions over the Indian subcontinent. Their study on the genesis of convection anomalies over the equatorial Indian Ocean revealed the following features:

1. Eastern equatorial Indian Ocean convection anomalies stimulates westward propagating descending Rossby waves and equatorial easterly anomalies in the eastern and central Indian Ocean.

2. The decreasing westward wind speed along the equator favours wind convergence in the western equatorial Indian Ocean.

3. This leads to moistening of the boundary layer increasing the convective energy of the source air and modifying the vertical stratification so that convection can occur again. This phase thus acts as a period during which atmosphere is preconditioned. Surface convergence leads the local rainfall anomaly by about 4 days.

4. During the next phase the surface moisture convergence increases rapidly in the in the central and western equatorial Indian Ocean due to westward decrease of zonal equatorial wind and confluence of equatorial winds.

5. During the last phase, the moisture convergence in the central equatorial Indian Ocean is reinforced by the equatorward flows and the convection.

They also found that the local Ocean - Atmosphere interaction also plays a significant role. When the central equatorial Indian Ocean is dry, the downward solar radiation increases because there are fewer clouds, while the heat loss from evaporation and entrainment decreases because wind speed decreases. These features, thus produce a warming of sea surface about 8 days later.

In order to look into the convective activity over the EET and WET during different BM and El Nino conditions, we have chosen four years, namely 1979, 1982, 1997 and 1998 (see table 2 for more details). We have computed the pentad precipitation anomalies from the pentad precipitation values by subtracting the long-term (20 year) mean from the pentad precipitation value of each grid. The long-term pentad mean precipitation value is based on 1979 to 1998 . 
Figure 4 depicts the latitude time section of the precipitation anomalies for the year 1979. From the figure, it can be seen that the western and eastern sections of the equatorial trough behaved differently during the BM conditions. The EET region showed large positive anomalies prior to and during the BM conditions. The WET region on the other hand exhibited only small positive anomalies prior to and during the $\mathrm{BM}$ conditions during this year.

In the case of a deficit and no BM conditions year (1982), the EET region showed large negative anomalies indicating that the convection was weak over this region during most of the monsoon season (figure 5). In case of WET, the negative anomalies though present were relatively weak. In the case of a normal and no BM conditions and an El Nino year (1997), both regions (WET and EET) exhibited weak negative anomalies (figure 6). Unlike in 1982, large positive anomalies were present in 1997 in the belt $0^{\circ}-30^{\circ} \mathrm{N}$, indicating intense convective activity over the Indian subcontinent as compared to the trough region. In the case of an year with a prolonged break and normal monsoon year, 1998, there were large positive anomalies prior to and during the breaks (figure 7), indicating that both regions were convectively active with the EET being the most active of all the three regions (figure 7, bottom figure).

Table 3 gives the correlation coefficients between the CIR, WET and EET. From the table it can be seen that, during the years when there were long breaks, such as 1979 and 1998, there is an inverse relation between CIR rainfall and EET which is statistically significant. In case of drought years and non El Nino years (1979 and 1986) there is a negative and significant relationship. In case of excess years, there is no relationship between CIR rainfall and both ET and EET, but there is a positive relationship between the WET and the CIR rainfall. In case of normal and non El Nino years, the relationship between CIR rainfall and EET are complex; during some years $(1980,1981,1989)$ there is no relationship and a few years $(1984,1985$, $1990,1991)$ there is negative but insignificant relationship. Further, in some year (1993) there is positive and significant relationship between WET and EET and CIR, whilst in some other years $(1995,1996$ and 1998) there is negative and significant relationship between the EET and CIR.

Table 4 gives the correlation coefficients between the AIR, WET and EET. From the table it can be seen that, during a deficit year 1979, there is a negative and significant correlation between EET with the AIR. This type of relationship between the AIR and EET, fails during a normal monsoon year, such as 1998. The WET exhibits a positive relationship with the AIR. Further it was found that the EET was positively and significantly correlated with the AIR in the year when there were no BM conditions and it was one of the strongest El Nino year (1997). The 
relationship between the equatorial trough regions and the monsoon activity over the CIR and AIR breaks during excess rainfall and non El Nino years (1983 and 1988).

Figure 8 gives the time - longitude plot of pentad precipitation averaged over the region $10^{\circ} \mathrm{S}$ $10^{\circ} \mathrm{N}$. In case of the deficit years with no break in monsoon conditions (1982 and 1992) the EET was quite active and so were the central and eastern Pacific ocean regions. Jospeh (1990), Rajeevan (1993) and Pai (1997) have obtained similar results. In case of normal (1997) and excess (1994) El Nino years with no breaks, the ET was weak or inactive, as the convection had shifted to the eastern Pacific sector. During excess monsoon and non El Nino years (1983 and 1988), the Indian Ocean sector was active as compared to the central and eastern parts of the Pacific region. In case of deficit and non El Nino years, the central Pacific region was equally active as the EET region. In case of deficit and El Nino years (1987 and 1992), the EET as well as the central and eastern Pacific regions were active.

\section{Conclusions}

- The ET especially the EET is more active during the years when there were pro-longed BM conditions (1979 \& 1998).

- The probability of occurrence of no BM situations is more in an El Nino year.

- No BM does not necessarily guarantee active monsoon conditions over the Indian subcontinent throughout the monsoon season. It is a combination of factors such as the number of synoptic systems together with the convective activity over the ET (EET or WET) in the Indian Ocean play a vital role in the monsoon activity and rainfall distribution over the Indian subcontinent.

\section{Acknowledgements}

The authors are thankful to the Global Precipitation Climatology Project of the World Data Center for Meteorology, Asheville, U.S.A for providing the GPCP data. The rainfall data for the present study is obtained from the Indian Institute of Tropical Meteorology. They would like to thank to two anonymous reviewers for their critical comments that helped in vastly improving an earlier version of the manuscript and making the ideas clearer. Freeware ferret was used for the analysis. The two of the authors (M.R.R.K and S.S.C.S) would like to thank the DST for the financial support. 


\section{References}

Ananthakrishnan, R., Pathan, J.M., Aralikatti, S.S. 1983. The Onset phase of the southwest monsoon, Current Science, 52, 155-164.

Baumgartner, A., and Reichel, E., 1975, The World Water Balance: Mean Annual Global, Continental and Maritime Precipitation, Evaporation and Runoff. Elsevier, Amsterdam, 179 pp.

Barrett, E.C., and Beaumont, M.J., 1994. Satellite rainfall monitoring: an overview. Remote Sensing of Environment, 11, 23-48.

Cadet, D., Olory Togbe, P., 1981. Analysis of super pressure balloon trajectories and conventional observations over the Indian Ocean during different phases of 1975 southwest monsoon. Monsoon Dynamics, Ed.: J.Lighthill and R.P.Pearce, Cambridge University Press, Cambridge U.K., 287-308.

De, U.S., Lele, R.R., and Natu, J.C., 1998. Breaks in Southwest Monsoon PrePublished Scientific Report No.1998/3, India Meteorological Department, Meteorological Office, Pune - 411 005, India.

Gadgil, S., Vinayachnadran, P.N., and Francis, P.A., 2003. Droughts of the Indian Summer Monsoon: Role of clouds over the Indian Ocean, Current Science, 85, 1713-1719.

Gadgil, S., and Jospeh, P.V., 2003. On the breaks of the Indian Monsoon, Proceedings of Indian Academy of Sciences (Earth and Planetary Sciences), 112, 529-558.

Goswami, B.N., 1994. Dynamical predictability of seasonal monsoon rainfall: Problems and Prospects, Proceedings of Indian Academy of Sciences, 60A, 101-120.

Huffman, G, J., Adler, R.F., Rudolf, B., Schneider, U., Keehn, P.R., 1995. Global precipitation estimates based on a technifor combining satellite based estimates, rain gauge analysis, and NWP model precipitation information. Journal of Climate, 8, 1284-1295.

Huffman, G, J., Adler, R.F., Arkin, P., Chang, A., Ferraro, R., Gruber, A., Janowiak, J., McNab, A., Rudolf, B., Schneider, U., 1997: The Global Precipitation Climatology Project (GPCP) combined precipitation data set, Bulletin American Meteorological Society, 78, 5-20.

Johri, A.P., Prasad, O., 1990. Interaction of southern hemispheric Equatorial Trough with the southwest monsoon circulation during severe drought years, Mausam, 41(4), 587-602.

Joseph, P.V., 1990. Monsoon variability in relation to equatorial trough activity over Indian and western pacific Oceans. Mausam, 41, 291-296. 
Kalnay, E., et al., 1996, The NCEP/NCAR 40-Year Reanalysis Project. Bulletin of American Meteorological Society, 77, 437-471.

Krishnamurti, T.N., Bhalme, H.N., 1976. Oscillations of a monsoon system. Journal of Atmospheric Sciences, 33, 1937-1954.

Murakami, T., Frydrich, M., 1974. On the preferred period of upper wind fluctuations during summer monsoon. Journal of Atmospheric Sciences, 31, 1549-1555.

Murakami, M., 1976. Analysis of summer monsoon fluctuations over India. Journal of Meteorological Society of Japan, 54, 15-31.

Pai, D.S., 1997. A diagnostic study of interannual variability of Indian summer monsoon using outgoing longwave radiation (OLR) data, Mausam, 48, 55-64.

Parathasarathy, B., Munot, A, A., Kothawale, D.R., 1994. All India monthly and seasonal rainfall series: 1871-1993. Theoretical and Applied Climatology, 49, 217-224.

Prasad, O., Mishra, D.K., and Jain, R.K., 1983. Satellite observed cloud distribution over Indian Ocean during southwest monsoon season. Mausam, 34(4), 449-454.

Prasad, O., Rama Sastry, A.A., Hansada, A.K., De, U.S., 1988. Role of Southern Hemispheric Equatorial Trough in Medium Range Forecasting. Mausam, 39(2), 201-206.

Rajeevan, M., 1993. Upper tropospheric circulation and thermal anomalies over central Asia associated with major droughts and floods in India. Current Science, 64, 244 $-247$.

Ramamurty, K., 1969. Monsoons of India, some aspects of the 'Break in the Indian Southwest Monsoon during July and August. Forecasting Manual No.IV-18.3. India Meteorological Department, Pune. India. 1-57.

Ramesh Kumar, M.R., Uma R Prabhu Dessai, 2004. A new criterion for identifying breaks in monsoon conditions over the Indian subcontinent, Geophysical Research Letters, 31, L18201, doi: 10.1029/2004GL020562.

Ramesh Kumar, M.R., Sreejith, O.P., 2005. On some aspects of precipitation over tropical Indian Ocean using satellite data, International Journal of Remote Sensing (in Press).

Sadhurm, Y., Sastry, J, S., 1987. Structure of the atmospheric boundary layer over central equatorial Indian ocean during southwest monsoon season. Contributions in Marine Sciences, T.S.S. Rao, R. Natarajan, B.N. Desai, G.N.Swamy and S.R.Bhat (Editors), 175-188. 
Sikka, D.R., Gadgil, S., 1980. On the maximum cloud zone and the ITCZ over Indian longitudes during the southwest monsoon. Monthly Weather Review, 108, 18401853.

Swapna, P., Ramesh Kumar, M.R., 2002. Role of low level flow on the summer monsoon rainfall during two contrasting monsoon years, Journal of Indian Geophysical Union, 6(3), 123-137.

Wang, Bin., Webster, P.J., and Teng, Haiyan., 2005. Antecedents and self induction of active-break south Asian monsoon unraveled by satellites, Geophysical Research Letters, 32, L04704, doi:10.1029/2004GL020996.

Yin, Xungang., Gruber, A., and Arkin, P., 2004. Comparison of the GPCP and CMAP Merged gauge satellite monthly precipitation products for the period 1979-2001. Journal of Hydrometeorology, 5, 1207-1222. 


\section{Table captions}

Table 1: Correlation coefficients for satellite estimates compared with the island stations data over the Arabian Sea and Bay of Bengal. The spatial resolution is $1^{\circ} \mathrm{X} 1^{\circ}$ for GPCP, $0.25^{\circ} \mathrm{X} 0.25^{\circ}$ for $\mathrm{TMI}$ and $2.5^{\circ} \mathrm{X} 2.5^{\circ}$ for NCEP/NCAR reanalysis.

Table 2: The break period and the number of break days (frequency) during the monsoon season for the study period.

Table 3: Correlation coefficients between Central India Rainfall $\quad\left(72^{0} \mathrm{E}-84^{0} \mathrm{E} ; 20^{0} \mathrm{~N}-24^{0} \mathrm{~N}\right)$ and all India rainfall (AIR) with the Western Equatorial trough $\left(60^{\circ} \mathrm{E}-80^{0} \mathrm{E} ; 0^{\circ}-10^{\circ} \mathrm{S}\right)$ and the Eastern Equatorial Trough $\left(80^{0} \mathrm{E}-100^{0} \mathrm{E} ; 0^{0}-10^{0} \mathrm{~S}\right)$. Only those years for which the correlation coefficients are statistically significant are presented. The superscripts $1,2,3$ and 4 stand for statistical significance at $0.10,0.05,0.02$ and $0.01 \%$ respectively. 


\section{Figure Captions}

Figure 1: Map showing the study areas used in the present study

a) Central Indian Region $\left(72^{\circ} \mathrm{E}-88^{\circ} \mathrm{E} ; 20^{\circ} \mathrm{N}-24^{\circ} \mathrm{N}\right)$

b) Western Equatorial Trough (WET) region $\left(60^{\circ} \mathrm{E}-80^{\circ} \mathrm{E} ; 0^{\circ}-10^{\circ} \mathrm{S}\right)$

c) Eastern Equatorial Trough (EET) region $\left(80^{\circ} \mathrm{E}-100^{\circ} \mathrm{E} ; 0^{\circ}-10^{\circ} \mathrm{S}\right)$

Figure 2: Seasonal mean precipitation over the tropical Indian Ocean and Indian sub continent for the study period (1979-1998).

Figure 3: Precipitation (mm/pentad) over the ET for the study period and break in monsoon days (represented by shaded area).

Figure 4: Time Latitude section of pentad precipitation anomalies $(\mathrm{mm} / \mathrm{pentad})$ averaged over the WET (top figure) and EET (bottom figure) for 1979.

Figure 5: Time Latitude section of pentad precipitation anomalies $(\mathrm{mm} / \mathrm{pentad})$ averaged over the WET (top figure) and EET ( bottom figure) for 1982.

Figure 6: Time Latitude section of pentad precipitation anomalies $(\mathrm{mm} / \mathrm{pentad})$ averaged over the WET (top figure) and EET ( bottom figure) for 1997.

Figure 7: Time Latitude section of pentad precipitation anomalies $(\mathrm{mm} / \mathrm{pentad})$ averaged over the WET (top figure) and EET ( bottom figure) for 1998.

Figure 8: Time Longitude section of pentad precipitation $(\mathrm{mm} /$ pentad) averaged over the equatorial region $\left(10^{\circ} \mathrm{S}-10^{\circ} \mathrm{N}\right)$ for the period 1979 to 1998 . 
Table 1: Correlation coefficients for satellite estimates compared with the island stations data over the Arabian Sea and Bay of Bengal. The spatial resolution is $1^{\circ} \mathrm{X} 1^{\circ}$ for GPCP, $0.25^{\circ} \mathrm{X} 0.25^{\circ}$ for $\mathrm{TMI}$ and $2.5^{\circ} \mathrm{X} 2.5^{\circ}$ for $\mathrm{NCEP} / \mathrm{NCAR}$ reanalysis.

\begin{tabular}{|c|c|c|c|}
\hline Satellite/ Time & $\begin{array}{c}\text { GPCP } \\
\left(1^{0} \mathrm{X} 1^{0}\right)\end{array}$ & $\begin{array}{c}\text { TMI } \\
\left(0.25^{0} \mathrm{X} 0.25^{0}\right)\end{array}$ & $\begin{array}{c}\text { NCEP } \\
\left(2.5^{0} \mathrm{X} 2.5^{0}\right)\end{array}$ \\
\hline One Day & 0.29 & 0.14 & 0.21 \\
\hline 5 Days & 0.62 & 0.37 & 0.44 \\
\hline 10 Days & 0.72 & 0.47 & 0.54 \\
\hline One Month & 0.79 & 0.67 & 0.61 \\
\hline
\end{tabular}


Table 2: The break period and the number of break days (frequency) during the monsoon season for the study period.

\begin{tabular}{|c|c|c|c|c|}
\hline Year & Period & $\begin{array}{l}\text { No. of break } \\
\text { days (No. of } \\
\text { breaks) }\end{array}$ & $\begin{array}{l}\text { All India } \\
\text { Rainfall } \\
(\mathrm{mm})\end{array}$ & Remarks \\
\hline 1979 & $\begin{array}{l}\text { 17-23 July; } \\
15 \text { August-3 September. }\end{array}$ & $27(2)$ & 707.9 & $\begin{array}{l}\text { Deficit and non } \text { El } \\
\text { Nino }\end{array}$ \\
\hline 1980 & $17-20$ July & $4(1)$ & 882.8 & Normal and non El Nino \\
\hline 1981 & $\begin{array}{l}26-30 \text { July } \\
23-27 \text { August }\end{array}$ & $10(2)$ & 852.0 & Normal and non El Nino \\
\hline 1982 & ---------- & -------- & 735.4 & Deficit and El Nino \\
\hline 1983 & $22-25$ August & $4(1)$ & 955.8 & Excess and non El Nino \\
\hline 1984 & $20-24$ July & $5(1)$ & 836.7 & Normal and non El Nino \\
\hline 1985 & $22-25$ August & $4(1)$ & 760.0 & Normal and non El Nino \\
\hline 1986 & $\begin{array}{l}23-26 \text { August } \\
29 \text { August }-3 \text { September }\end{array}$ & $10(2)$ & 759.0 & Deficit and non El Nino \\
\hline 1987 & 28 July - 1 August & $5(1)$ & 697.3 & Deficit and El Nino \\
\hline 1988 & $\begin{array}{l}\text { 5-8 July } \\
\text { 13-15 August }\end{array}$ & $7(2)$ & 961.5 & Excess and Non El Nino \\
\hline 1989 & $\begin{array}{l}\text { 10-12 July } \\
\text { 29-31 July }\end{array}$ & $6(2)$ & 866.7 & Normal and non El Nino \\
\hline 1990 & $\begin{array}{l}\text { 8-10 July } \\
\text { 27-31 July }\end{array}$ & $8(2)$ & 908.6 & Normal and non El Nino \\
\hline 1991 & 3-9 September & $7(1)$ & 784.7 & Normal and non El Nino \\
\hline 1992 & ----------- & ------ & 784.7 & Normal and El Nino \\
\hline 1993 & 19-21 July & $3(1)$ & 896.6 & Normal and non El Nino \\
\hline 1994 & ---------- & ------ & 938.2 & Excess and El Nino \\
\hline 1995 & $12-15$ August & $4(1)$ & 790.3 & Normal and non El Nino \\
\hline 1996 & $1-5$ July & $5(1)$ & 852.4 & Normal and non El Nino \\
\hline 1997 & ------- & $\begin{array}{ll}---- \\
\end{array}$ & 870.6 & Normal and El Nino \\
\hline 1998 & $\begin{array}{l}16-25 \text { July } \\
21-31 \text { August }\end{array}$ & $21(2)$ & 851.2 & Normal and non El Nino \\
\hline
\end{tabular}


Table 3: Correlation coefficients between Central India Rainfall $\left(72^{0} \mathrm{E}-84^{0} \mathrm{E} ; 20^{0} \mathrm{~N}-24^{0} \mathrm{~N}\right)$ and the All India Rainfall (AIR) with the Western Equatorial trough $\left(60^{\circ} \mathrm{E}-80^{\circ} \mathrm{E} ; 0^{0}-10^{0} \mathrm{~S}\right)$ and the Eastern Equatorial Trough $\left(80^{\circ} \mathrm{E}-100^{\circ} \mathrm{E} ; 0^{0}-10^{\circ} \mathrm{S}\right)$. Only years for which the correlation is statistically significant are presented. The superscripts $1,2,3$ and 4 stand for statistical significance at $0.10,0.05,0.02$ and $0.01 \%$ respectively.

\begin{tabular}{|c|c|c|c|c|}
\hline \multirow[t]{2}{*}{ Year } & \multicolumn{2}{|c|}{ Central India Rainfall } & \multicolumn{2}{|c|}{ All India Rainfall } \\
\hline & WET & EET & WET & EET \\
\hline 1979 & -0.23 & $-0.51^{4}$ & -0.21 & $-0.48^{3}$ \\
\hline 1982 & $-0.39^{1}$ & -0.19 & $-0.44^{2}$ & -0.33 \\
\hline 1987 & $-0.41^{2}$ & -0.21 & $-0.47^{3}$ & -0.20 \\
\hline 1990 & 0.07 & -0.21 & -0.23 & $-0.35^{1}$ \\
\hline 1992 & -0.06 & -0.32 & -0.16 & $-0.46^{3}$ \\
\hline 1995 & -0.17 & $-0.47^{3}$ & $-0.40^{2}$ & -0.07 \\
\hline 1996 & $-0.37^{1}$ & -0.32 & $-0.37^{1}$ & -0.32 \\
\hline 1997 & -0.07 & 0.13 & -0.11 & $0.34^{1}$ \\
\hline 1998 & 0.18 & $-0.34^{1}$ & 0.26 & -0.16 \\
\hline
\end{tabular}




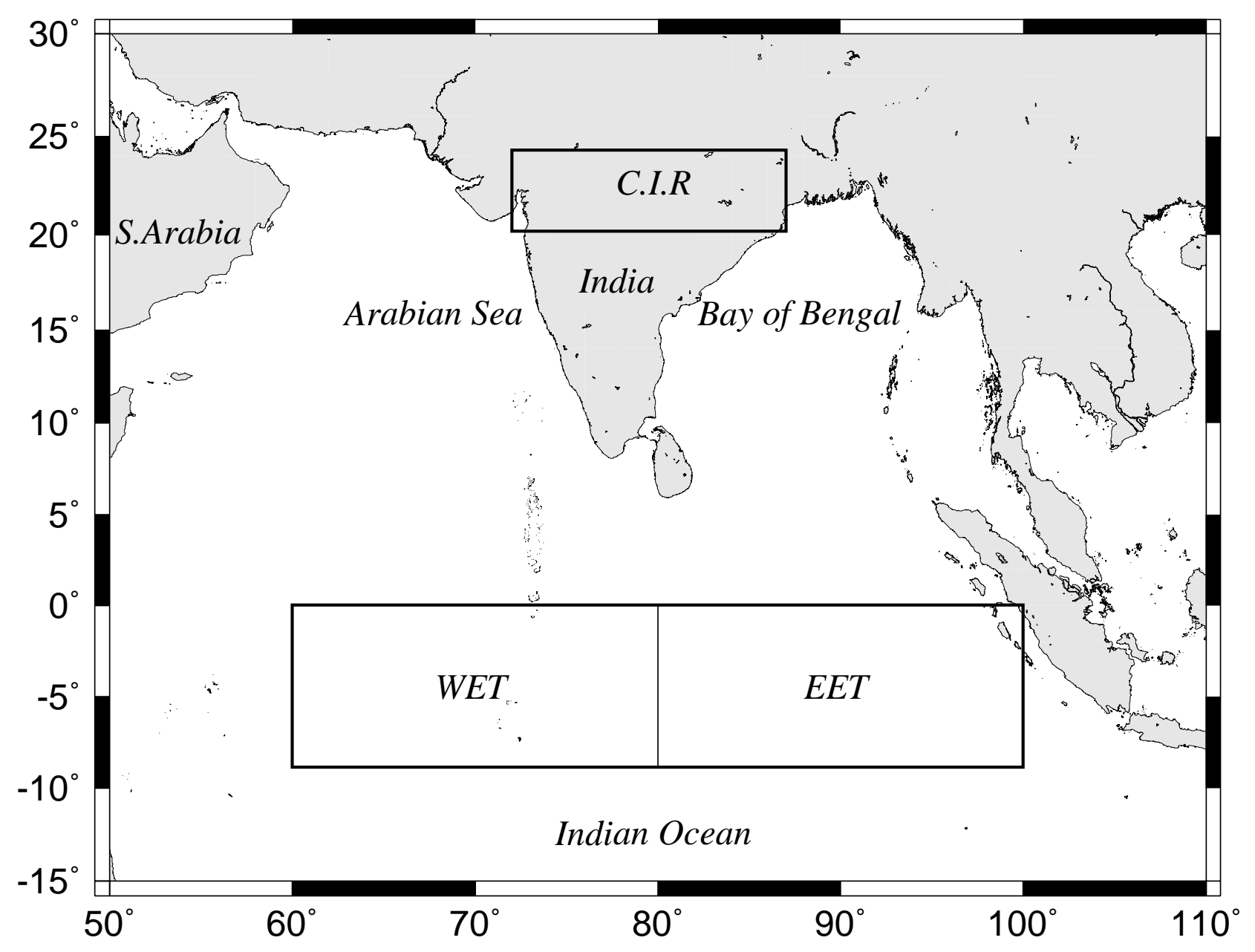




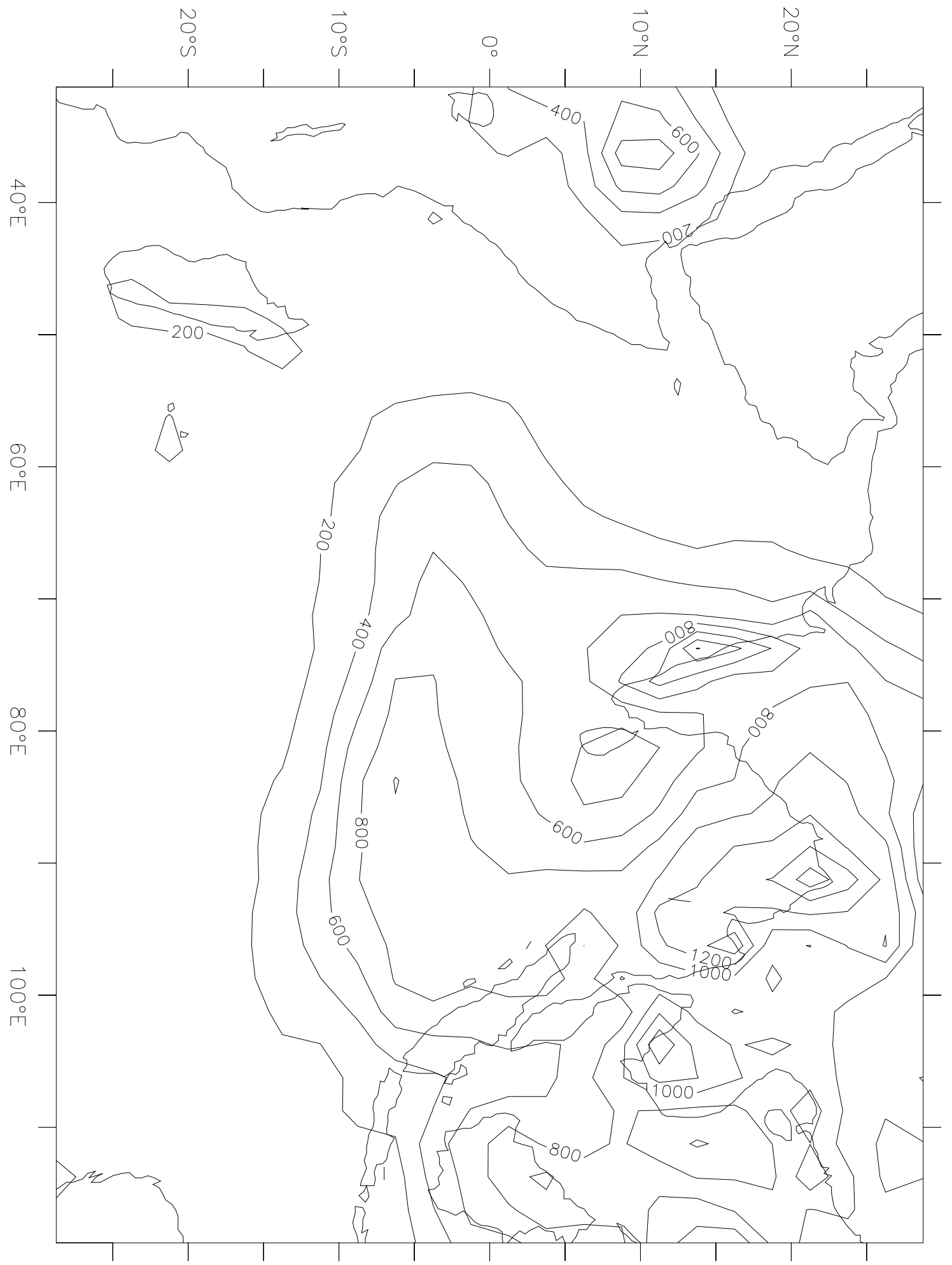




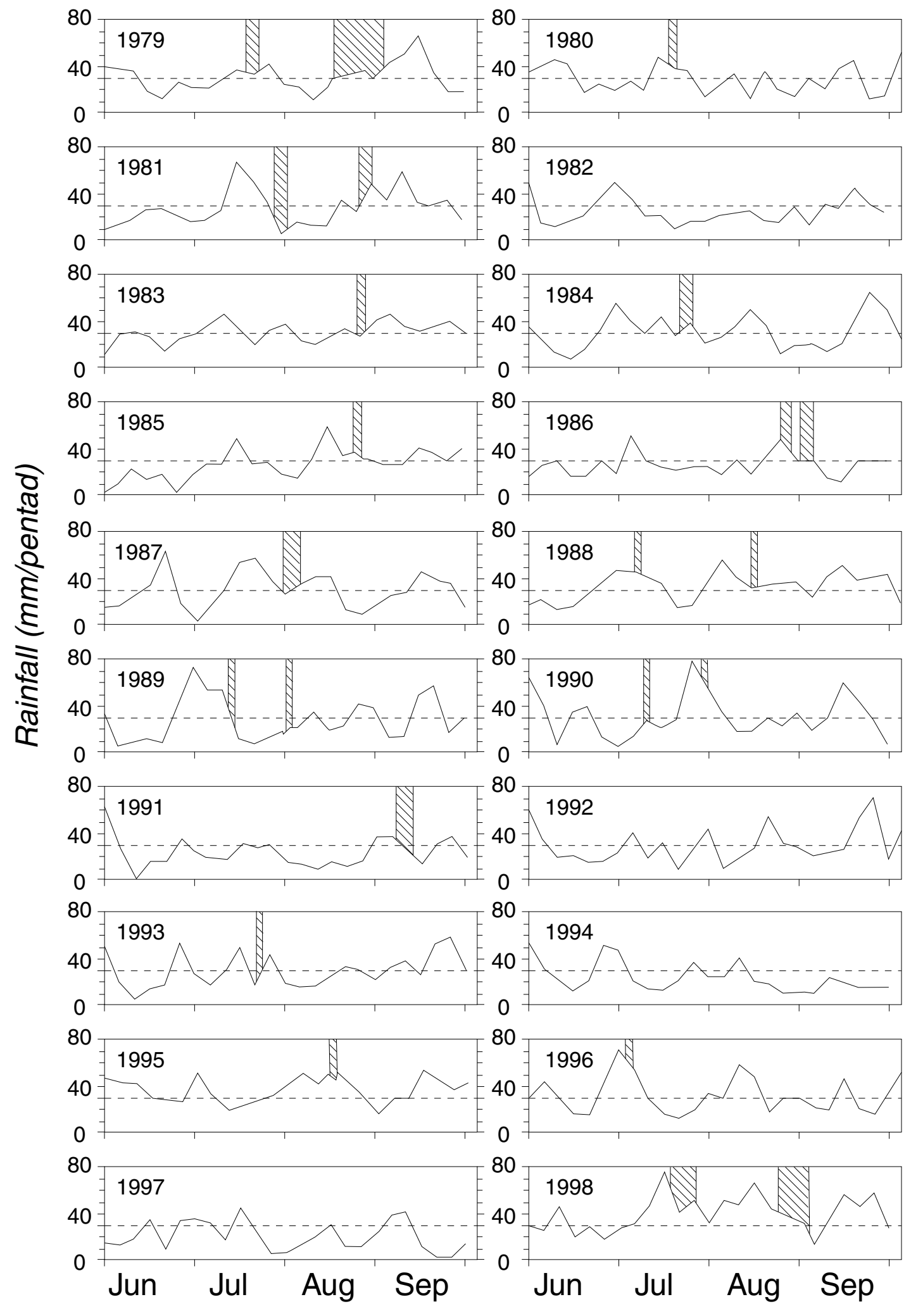



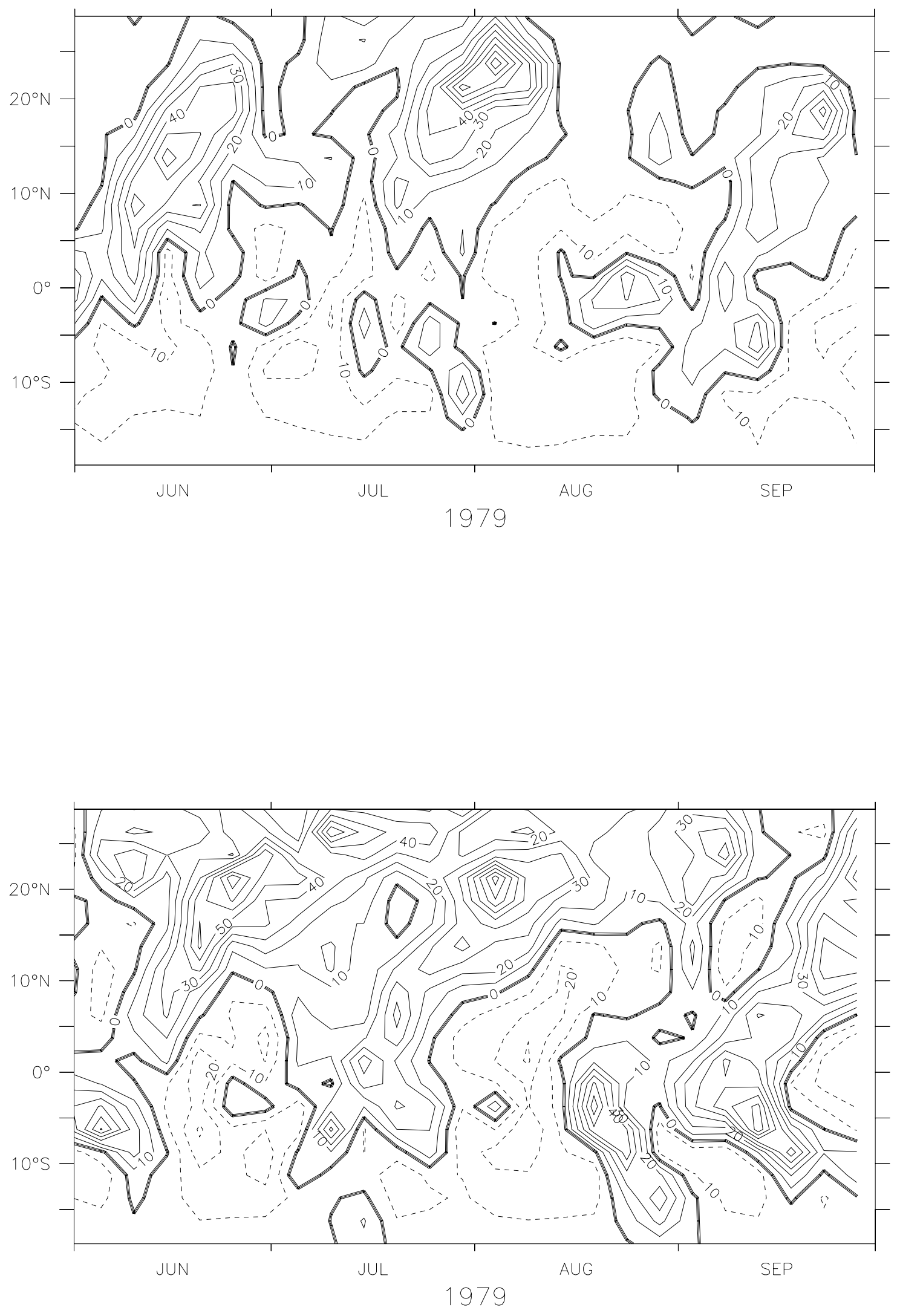

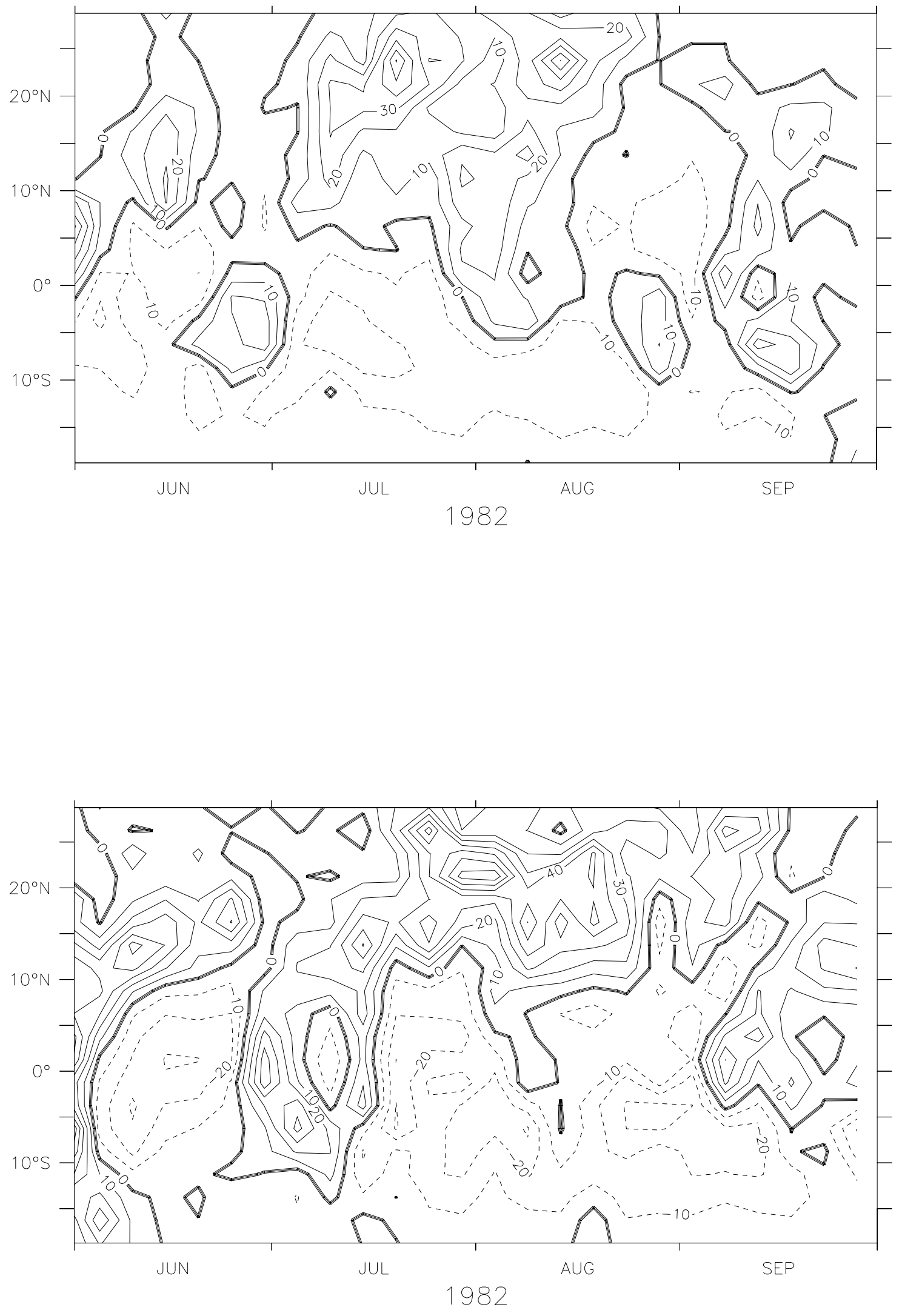

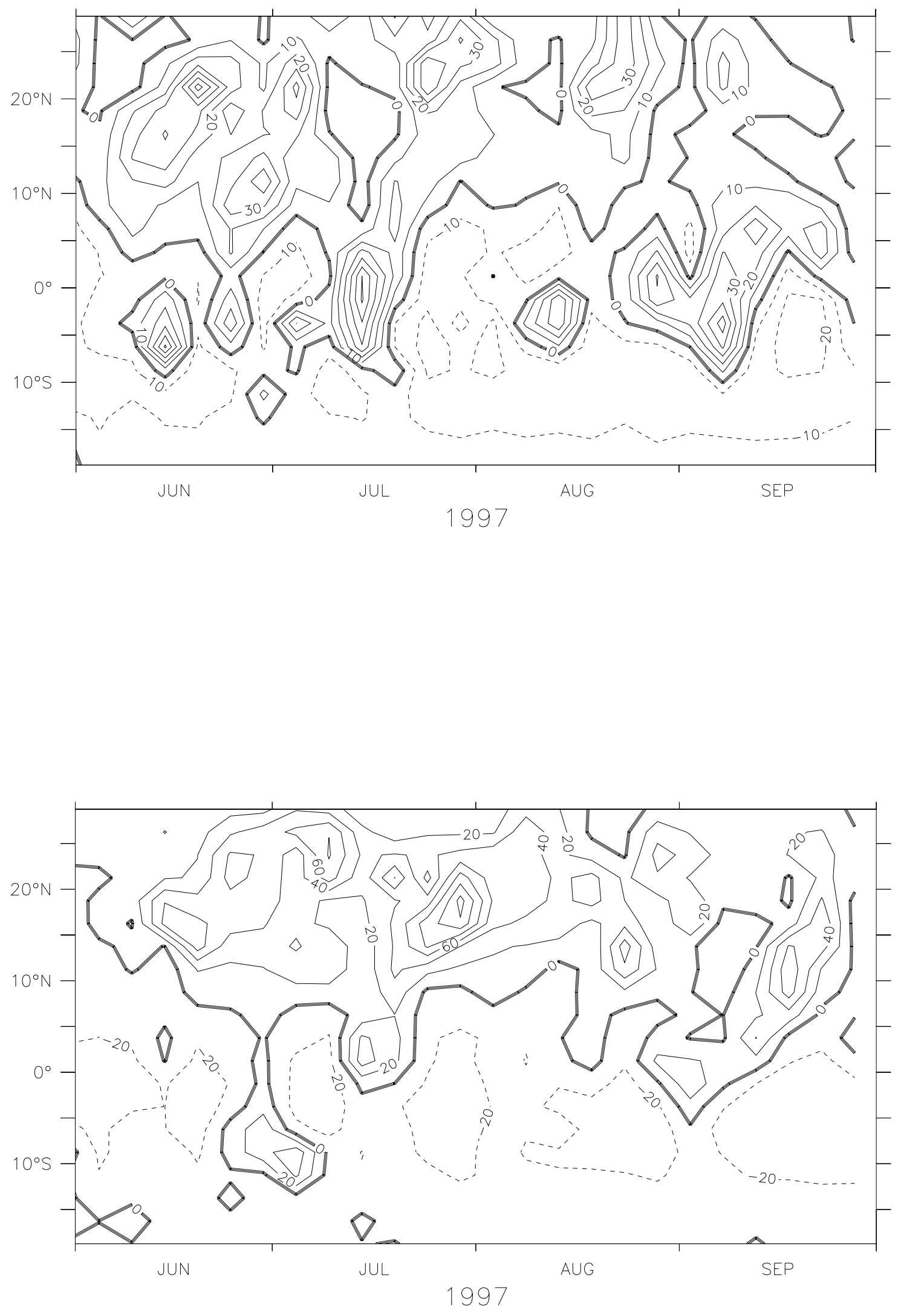

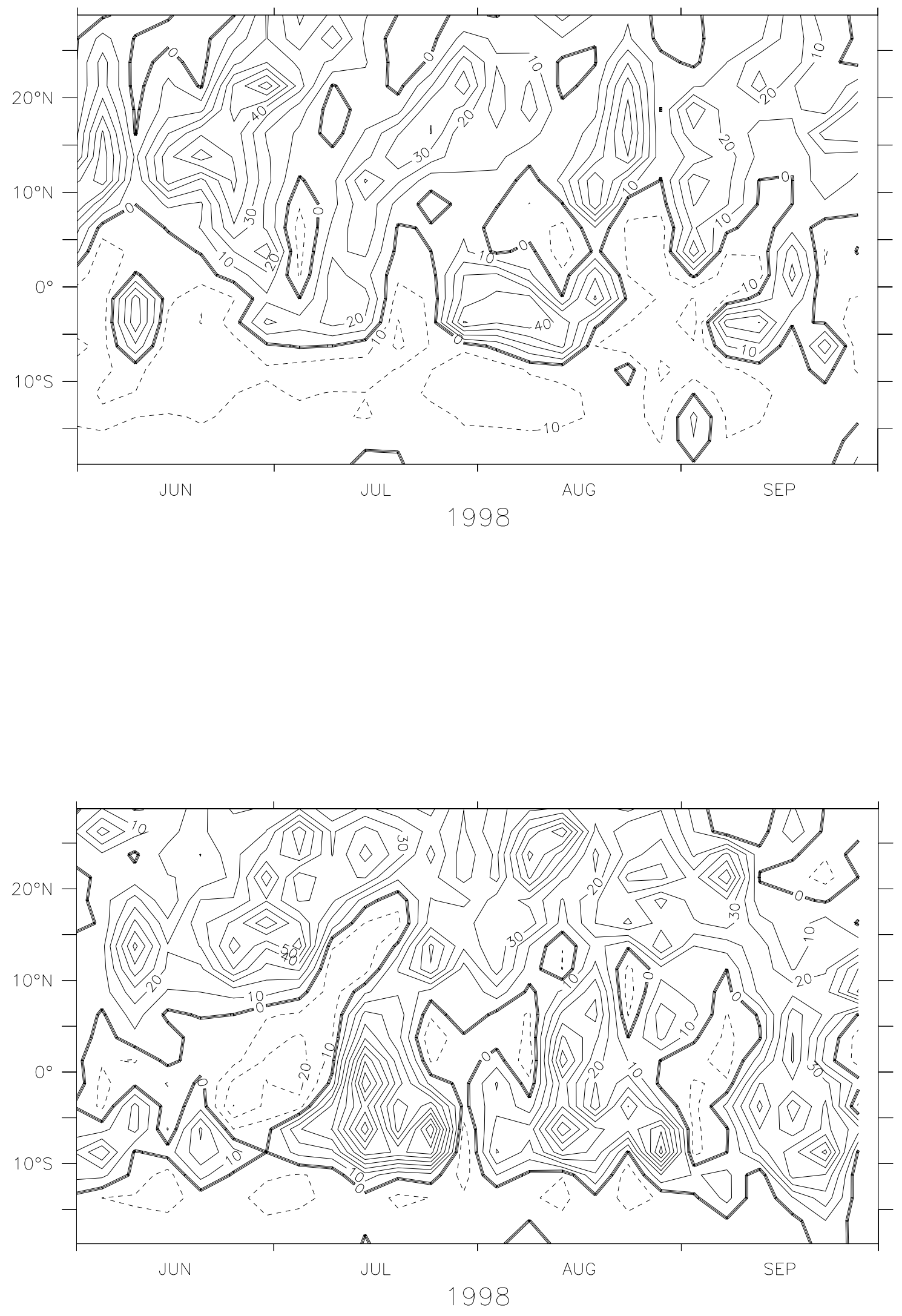


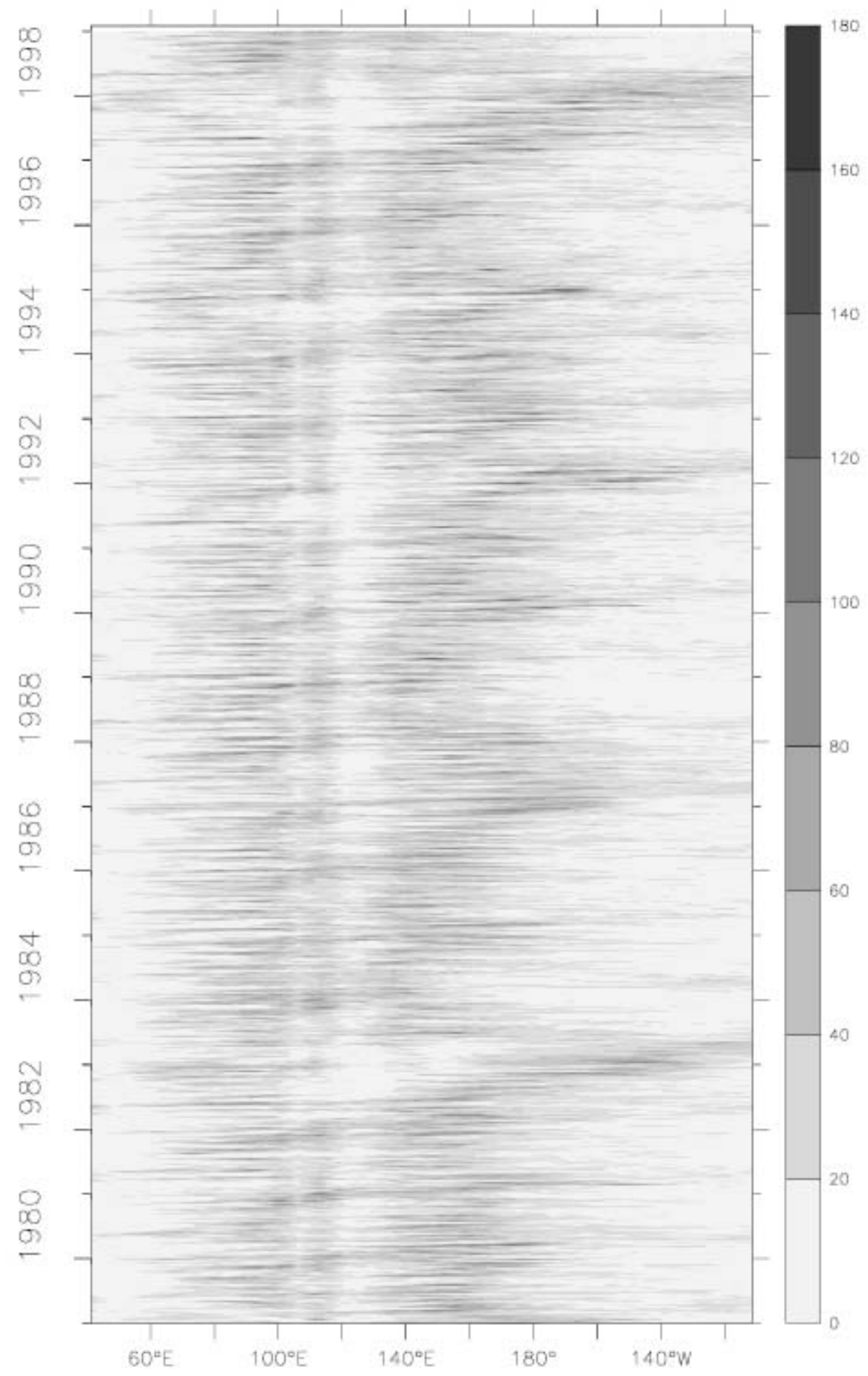

